\title{
An appraisal of the Pentecostal eco-theology and environmental consciousness among youths in Parklands Baptist Church, Kenya
}

\begin{tabular}{|c|c|}
\hline \multicolumn{2}{|c|}{$\begin{array}{l}\text { Authors: } \\
\text { Loreen Maseno }{ }^{1,2} \text { @ } \\
\text { King'asia Mamati }^{3} \text { — }\end{array}$} \\
\hline \multicolumn{2}{|c|}{$\begin{array}{l}\text { Affiliations: } \\
{ }^{1} \text { Department of Biblical and } \\
\text { Ancient Studies, College of } \\
\text { Human Sciences, University } \\
\text { of South Africa, Pretoria, } \\
\text { South Africa }\end{array}$} \\
\hline \multicolumn{2}{|c|}{$\begin{array}{l}\text { 2Department of Religion, } \\
\text { Theology and Philosophy, } \\
\text { School of Arts and Social } \\
\text { Sciences, Maseno University, } \\
\text { Kisumu, Kenya }\end{array}$} \\
\hline \multicolumn{2}{|c|}{$\begin{array}{l}\text { 3Department of Social and } \\
\text { Cultural Anthropology, } \\
\text { Faculty of Humanities, } \\
\text { University of Cologne, } \\
\text { Cologne, Germany }\end{array}$} \\
\hline \multicolumn{2}{|c|}{$\begin{array}{l}\text { Corresponding author: } \\
\text { Loreen Maseno, } \\
\text { loreenmas@gmail.com }\end{array}$} \\
\hline \multicolumn{2}{|c|}{$\begin{array}{l}\text { Dates: } \\
\text { Received: } 14 \text { May } 2021 \\
\text { Accepted: } 20 \text { Aug. } 2021 \\
\text { Published: } 22 \text { Nov. } 2021\end{array}$} \\
\hline \multicolumn{2}{|c|}{$\begin{array}{l}\text { How to cite this article: } \\
\text { Maseno, L., Mamati, K., 2021, } \\
\text { 'An appraisal of the } \\
\text { Pentecostal eco-theology and } \\
\text { environmental consciousness } \\
\text { among youths in Parklands } \\
\text { Baptist Church, Kenya', HTS } \\
\text { Teologiese Studies/ } \\
\text { Theological Studies 77(2), } \\
\text { a6840. https://doi.org/ } \\
\text { 10.4102/hts.v77i2.6840 }\end{array}$} \\
\hline \multicolumn{2}{|c|}{$\begin{array}{l}\text { Copyright: } \\
\text { (c) 2021. The Authors. } \\
\text { Licensee: AOSIS. This work } \\
\text { is licensed under the } \\
\text { Creative Commons } \\
\text { Attribution License. }\end{array}$} \\
\hline \multicolumn{2}{|l|}{ Read onlir } \\
\hline 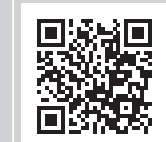 & $\begin{array}{l}\text { Scan this QR } \\
\text { code with your } \\
\text { smart phone or } \\
\text { mobile device } \\
\text { to read online. }\end{array}$ \\
\hline
\end{tabular}

The younger generation in different countries have been said to be growing into environmental consciousness. Are youths in the Kenyan religious landscape aware of the environmental issues? Is environmental consciousness evident among Pentecostal youths? On the one hand, environmental consciousness based on anthropocentric perspective promotes the view that only human beings and their interests are to be considered. On the other hand, environmental consciousness grounded in eco-centric viewpoint insists that natures' value cannot be reduced to only what promotes human well-being. The researchers adopted a descriptive design for the study. The tools for data collection included participant observation and literature review.

Contribution: This article critically examines the Parklands Baptist Church (PBC) in Kenya vision 2040 strategy, sermons and congregational programmes in relation to environmental stewardship. It considers how through these, PBC youths are mobilised in practical ways towards creation care to grow an awareness for the environment. It further points to the ways in which religious communities such as churches could be important instruments in enabling youths to have conviction and nudge them to be conscious of the environment as a divine mandate. For analysis, this article considers tenets of a credible eco-theology at PBC and its applicability.

Keywords: environmental consciousness; Pentecostal youths; eco-theology; Parklands Baptist; Kenya.

\section{Introduction}

A common feature among the Pentecostal movements is the youths. These churches or 'ministries' initially tend to have a younger, more formally educated, and consequently more Westernised leadership and membership. There are also young professionals and middle-class urban Africans among their numbers. In these churches, they are mobilised in practical ways and grow an awareness about various areas such as financial stewardship, creation care and determination for success. Given that the exponential growth of Pentecostalism has equally been forged and fuelled by aggressive evangelism, church planting, lay-mobilising cultures, lively music and the celebratory nature of worship, and the use of mass media communication technologies, it continues to attract the youths (Parsitau \& Mwaura 2014:9). It is, therefore, not possible to ignore the contribution and input of youths to these Pentecostal ministries and Churches in Kenya and beyond.

The burden of climate change will fall onto the shoulders of children and coming generations (Thunberg 2019). It is evident that younger generation of Pentecostals are growing into ecological consciousness and reject the scepticism of their parents and grandparents (Neuhauser 2018:1). Environmental consciousness enhances a general level of concern towards the well-being of creation. It comprises components such as: knowledge, experiences, awareness, concerns, values invoked in relation to creation care (Sarrica et al. 2016). ${ }^{1}$

Despite the different approaches and definitions of environmental consciousness, one important issue is the polarisation of environmental consciousness between the anthropocentric and ecocentric outlook. The main feature of the former is the anthropocentric pragmatic priority of human interests in its interaction with the natural world on their own patterns of development. In 1.Sarrica et. al. (2016) highlight environmental awareness, concern and consciousness.

Note: Special Collection: Youth, Faith, Climate Change and Environmental Consciousness: A Case for Sustainable Development, subedited by Jacques Beukes (University of Pretoria), Juliane Stork (Humboldt University, Berlin) and Ignatius Swart (University of the Western Cape) 
contrast, an eco-centric environmental consciousness considers the environmental priority-oriented values. In which case, value is assigned to creation in itself. Often times, actual ecological consciousness includes both anthropocentric and eco-centric components, and requires the adoption of a decision (Panov 2013:380).

According to Anderson (2002:170), it is becoming increasingly difficult to define 'Pentecostalism' precisely, and if we persist with narrow perceptions of the term, we will escape reality. Further, he pointed out that:

In global North a rather limited, stereotyped and dogmatic understanding of 'Pentecostal' will immediately fail to recognise the great variety of different Pentecostal movements in most of the rest of the world, many of which arose quite independently of Western Pentecostalism and even of the Azusa Street movement. (p. 170)

This article will not delve into the finer demarcations of Pentecostalism, but explores how the Parklands Baptist Church (PBC) youths encounter the PBC vision 2040 strategy, faith sermons on environmental stewardship, and whether they are encouraged and mobilised into programmes and practical ways towards creation care. Suffice is to indicate that these group or formations are largely younger church movements, with relatively younger Church members drawn from across the Pentecostal landscape, and are characterised by an emphasis on salvation, deliverance and lively worship. These groups stress faith healing, exorcism, speaking in tongues (glossolalia), spontaneous prayer, prophecy, as well as laying an emphasis on visions and dreams visions (Parsitau 2014).

Theologically, the Pentecostal Churches are Christocentric; and common to these churches is that they all respond to the existential needs of the African worldview, offering a personal encounter with God through the power of the Spirit, healing from sickness, and deliverance from evil in all its manifestations (Anderson 2002). They also share an emphasis on the power of the Spirit with other Pentecostals, including many African Independent Churches (AICs). A particular focus on personal encounter with Christ (being 'born again'), long periods of individual and communal prayer, prayer for healing and for such problems as unemployment and poverty, deliverance from demons and the occult (this term often means traditional beliefs and witchcraft), the use of such spiritual gifts as speaking in tongues and (to a lesser extent) prophecy - these features more or less characterise all New Pentecostal churches (Anderson 2002:171).

The succeeding sections will delve deeper into Pentecostalism and environmental concerns to highlight how Kenya, like many other African countries, has experienced growth in Pentecostal churches but whose immediate urgency in environmental matters is at a primal stage. An overview of PBC shall be presented setting the stage for the PBC vision 2040 strategy framework, PBC sermons, programmes, and the role of PBC Youths in these. Finally, a consideration shall be made on what might a Pentecostal Eco-theology at PBC among the youths might look like. This shall be appraised using tenets of a credible eco-theology.

\section{Pentecostalism and environmental concern in Kenya}

Scholars have lamented the lack of environmental concern by Pentecostal churches because of the emphasis on themes such as materialism, consumerism, abundance and prosperity as a focus of their preaching and teaching, popularly regarded as prosperity Gospel. Golo (2014:338) argues that the NeoPentecostal quest for materialism, opulence and prosperity Gospel may have a negative impact on creation care and may further attenuate efforts against environment degradation. The gravity of the environmental crisis and climate change is a threat to each and everyone across the world, more particularly Africa for its low adaptive capacity. It's devastating effects will lead to food insecurity, flooding, drought, water stress, outbreak of diseases and population displacement (UNFCCC 2020). Conradie (2012) avers that the current environmental crisis in Africa and beyond provides the church with an opportunity for reformation, renewal and conversion among Protestant churches.

Some Pentecostals express almost no concern about environmental problems because of their worldview which values the supernatural while viewing nature as subordinate, dependent and temporary. Goins (1997) further asserts that the environmental crisis for Pentecostals is not problematic because the natural environment is of only relative value and is expected to be destroyed ultimately. In sum, he noted that the reasons Pentecostals lack concern about the eco-crisis are found in the Pentecostal tradition, their views of human and natural history, and the way Pentecostals apply scriptural interpretation (Goins 1997).

The argument that Christianity is the most anthropocentric religion the world has seen and bears a huge guilt of burden was made by White (1967) in a controversial seminal work. The aforesaid laid ground for blame and is cited as a reason for the lack of concern among Pentecostals from which it draws its roots. He further argued that the biblical dominion of humankind over nature in the creation narratives has led to exploitative attitude and behaviour by human beings (White 1967). Moreover, current churches in Africa are slow to act and respond to the environmental crisis thereby validating White's claim (Conradie 2012).

Nairobi, Kenya, like other African cities, has seen the concentration of Pentecostal and Charismatic churches more than double since the 1970s (Liu 2010). A study done in Nairobi collected new text data on the messages and sermons Pentecostal churches are delivering to congregants in Nairobi. The results obtained from 100 churches over a period of 1 year, were both an open-ended survey of a random sample of Pentecostal pastors and close readings of sermons collected from those pastors' churches. The data gathering efforts 
allowed the researchers to describe the most common topics being delivered in contemporary Pentecostal sermons in Nairobi. The topics included: (1) faith, overcoming victim mentality; (2) money through giving, praise, investment; (3) abundant future through purity; (4) fighting; and (5) suffering and perseverance. In sum, as assimilated from this study, sermons pointed to mental transformation, individual capabilities, self-worth, the need for perseverance, and spiritual warfare for success (McClendon \& Riedl 2015).

In some Pentecostal churches in Nairobi, the leadership has shown little concern for environmental issues. Maseno (2017) in a sample of Sunday sermons from three Pentecostal churches in Nairobi, namely, Jesus is Alive Ministries (JIAM), Faith Evangelistic Ministry (FEM), and PBC noted that it is only $\mathrm{PBC}$ that showed concern to environmental issues. The other two churches in the study were primarily concerned with the great commission of evangelising.

Nairobi continues to experience environmental degradation such as prolonged drought, pollution, floods and even water shortage as a result of human activities such as river pollution and massive forest destruction. Pentecostal churches are called upon to be proactive and take a decisive action in environmental issues. The strategic location of the church in the heart of Nairobi city, can play a significant role in achieving a sustainable environment for all, especially in a city that is facing numerous environmental problems.

Religious ecumenical bodies in the world have issued statements on the need to conserve the environment. For instance, dealing with climate change and environmental crisis, the World Council of Churches (WCC) focuses on two key pillars: care for creation and justice (World Council of Churches 2021). The WCC urged nations to advocate for 'just, participatory and sustainable environment' (World Council of Churches Executive Committee Statement on Climate Justice 2016:1-2). In addition, ecumenical bodies such as All African conference of churches have also issued statements highlighting the plight of the earth because of the environmental crisis. However, the challenge has been that those who are targeted rarely receive, read or respond to ecumenical statements on environmental issues (Conradie 2012). Churches could be an important instrument in enabling youths have conviction and be conscious of the environment as a divine mandate.

\section{Background information on Parklands Baptist Church}

The $\mathrm{PBC}^{2}$ began in 1967. In 1968, PBC moved to its first location on the junction of Ojijo Road and Chiromo Lane. It was situated here for more than 20 years (Kinyua 2000). From 1993 to 2000, a 3500-seater sanctuary was constructed in

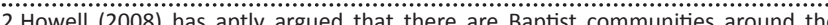
world that have been gretly influenced by Pentecostal growth. As such the practice (ith that he pre (italics mine) of the Baptist faith in different contexts varies, presenting a variety of shades under the same umbrella. An in-depth analysis of this phenomena in Argentina has been provided by Aasmundsen (2016:140-144)
Westlands and was dedicated that same year on 16 April 2000. The PBC currently boasts of a membership of over 6,000 , with a larger proportion being younger members (Kinyua 2000). It is generally agreed among scholars that Pentecostal churches, have relatively younger members and are characterised by an emphasis on salvation, deliverance, and lively worship (Anderson 2002). The PBC teens, college students and young professionals are encouraged, mobilised and included in church activities.

The PBC has a team of pastors led by the senior pastor Rev. Ambrose Nyangao such as the Pastor in charge of missions, Children's Pastor, Worship Pastor, Youths Pastor, and others. The leadership structure allows for elaborate operations of staff having a mission emphasis with a team of missionaries in the field reaching out to various people groups around the country and beyond.

The PBC runs several services each week: on Sunday, Wednesday and Friday. According to Kinyua (2000), there is a significant numerical and qualitative growth at PBC. He reckoned that attendance in worship has grown from 400 to 1500 within 14 years. Further he noted that the discipleship programme at PBS encompasses regular members who were found to be involved in the discipleship ministry. The depth of discipleship at PBC is such that it covers all ages and status of church attendees. At the same time, members are involved in missions and training even outside their church while some of their dedicated members have gone out to serve other churches, in various capacity such as pastoral ministry (Kinyua 2000).

In order to be visionary, PBC developed the 2040 vision strategy expounded below. The PBC celebrated 40 years of its existence in 2016. The theme of the celebration was 'Crossing Over', in reference to the Israelites crossing into Canaan, the Promised Land, after 40 years in the wilderness. It was at this time that the Vision 2040 was birthed. The church affirmed having a great task and destiny ahead and their faith in God's provision as they put into effect the Vision 2040.

The PBC has a church constitution, which gives the mandate of managing the affairs of the church to the Pastors and Deacons Board. It also provides for the Church Council which acts as an advisory body, and the Board of Trustees who hold the assets of the church in trust. This structure supports governance and provides for changes every 3 years as the seven Church trustees get to be chosen at the Annual General meetings. The PBC operates based on the practices of the Southern Baptist Convention of the United States of America (USA). The Southern Baptists, who need new constituencies among different groups, changed their policy on speaking in tongues in May 2015 (Shimron, Horton \& Yonat 2015). Clearly, there are differences between Baptists and Pentecostals. Baptist 
theology, on the one hand, emphasises the adult decision to become a Christian, the importance of water baptism, and joining a particular congregation as a sign of conversion having a particular historic experience. Pentecostal theology on the other hand emphasises speaking in tongues, direct experience of the presence of God and God's work among people through the power of the Holy Spirit.

\section{Parklands Baptist Church vision 2040 strategy framework}

The PBC vision 2040 as developed was a strategic framework for PBC's ministry transformation over the next 22 years. It was inspired by the possibilities and opportunities ahead and sought to achieve impactful ministry for growth and sustainability. This vision has the following seven pillars, namely, Pillar 1: God and Spiritual Cover, Pillar 2: Membership and Leadership Development, Pillar 3: Transformative Missions, Pillar 4: Infrastructure Development, Pillar 5: Investment and Resource Mobilisation Pillar, 6: Institutional Development, and Pillar 7: Implementation, Monitoring, Evaluation and Excellence Service Delivery. In sum, under the strategic framework rollout each congregant is encouraged to plug in based on their area of expertise or gifting. All members including the youths have a place in the implementation of the framework which should see implementation within the Westlands venue, Church Plants, Mission Stations and other locations identified for development (Parklands Baptist Church Vision 2040 Booklet 2019:6-9).

Pillar four considers infrastructure development, and whose components include: state-of-the-art physical infrastructure and cutting-edge technology that meets the spiritual, social and physical needs of the congregation, accommodates growth and demonstrates Christ's excellence. The main sanctuary of PBC is located in an upmarket area known for its serenity and well-manicured lawns. The entrance to the church compound and in the precincts there are several varieties of trees and shrubs that beautify the landscape. In addition, all main services are well draped and decorated with live flowers. These decorations have become a norm which is well appreciated by the congregation. Pillar four also considers the construction of multi-use facilities distinct to children, youths and adults that provide comfortable, conducive and safe environment, capturing Christ's excellence. A safe environment is envisioned in its totality, to include the physical and mental space that will allow for flourishing of their congregants. In all, pillar four goes further to indicate the provision of space for Recreational Centre, Open Space for Christian Fellowship that will take care of various groups and a Green environment conducive for children to play (Parklands Baptist Church Vision 2040 Booklet 2019:7-8). These elements spelled out in the strategic plan inculcate in the membership the direction that the ministry is taking and it's inclusion of safe, green and recreational environment.
The word green embedded in the strategic framework is of key importance. The PBC demonstrates a consciousness of the environment and the need to keep it green, flourishing and useful for recreation and fellowship. This reality brings on board congregational input and expectation on the Property Development and Management Committee of the PBC.

Pentecostal churches in Kenya have remarkable following and command especially among the urban youths who constitute the biggest chunk of Kenya population. The PBC church boasts of having a dynamic, tech savvy youths congregation, among its key pillars to achieve the Vision 2040. Kaunda (2015) posits that: 'Pentecostal churches have successfully maintained a strong public presence in the media, more than any other religious groups or social institutions. This huge media presence has made Pentecostalism appeal to wider audiences beyond their local churches' (p. 125) The PBC has capitalised on modern forms of communication, technology and social media as it maintains an active presence on social media to remain relevant to the youths. The church currently utilises social media platform such as YouTube and Facebook to broadcast their sermons, events and programmes. Furthermore, they have a website that is regularly updated and archives their weekly church sermons. This is in line with the PBC's aim of becoming a virtual church which is integral to their outreach mission (Parklands Baptist Church Vision 2040 Booklet 2019:10).

\section{Faith and the environment at Parklands Baptist Church}

Listening to some of the sermons given at PBC after the adoption of the Vision 2040 Strategy Framework, it is clear that there are references to the environment. Some excerpts of the sermons are as follows:

On 08 January 2017, the preacher of the second service preached on the topic, 'Theme 2017'. In sum, 2017 was said to be a year of amazing possibilities, God's purpose, proclamation, positioning and productivity:

God is the sufficient one. My brother was talking about the needs you have, the school fees you have and the all the kinds of business you have and this is an interesting month because sometimes it can be very hot and there is no rain and there are farmers who need water upon their gardens. Let me say this, when you see these kinds of things sometimes you just look for a verse. Let me give you one verse Zechariah 10:1 especially for the farmers right now. Zechariah 10:1 is an interesting verse for them. And we shall be praying for rain. This is what the bible says; Ask ye of the Lord rain in the time of the latter rain; so the Lord shall make bright clouds, and give them showers of rain, to every one grass in the field. So I want to declare this, for those farmers who are listening to me right now in Jesus name, may the Lord give you rain.... ${ }^{3}$

3.The context of this message as one of the earliest full Sunday service in the year 2017 was that the senior pastor was laying ground on the theme for the year. This 2017 was that the senior pastor was laying ground on the theme for the year. This
sermon referenced nature and how humans interact with it through processes such as farming. 
During another service on 15 January 2017 at PBC, Associate Pastor, made a prayer (Maseno 2017): ${ }^{4}$

As we lift our hands to God, may we together ask for rain because God is the rain maker and the streams of God are full of water. My God, we pray very quickly that may you send rain in the name of Jesus because you are able. My God, may you fill our dams again, may you fill our rivers again. May you fill our farms again with water. May we see green everywhere all over this country. Lord we ask for rain today and we know you hear us and will answer us. (p. 345)

From the above statements, it is clear that PBC leadership is aware of the climatic challenges in the country, and that they are in touch with the reality on the ground. At the same time, their outlook is that in which the farmers, the crops, the garden and dams should be well watered. Bedford-Strohm (2007) with reference to the Nature-Centred Approach asserted that human life is embedded in nature and both of them together are an expression of God's creative power. The orientation in this case is towards the earth as a whole and all its parts, whether they are alive or not. In this approach, reference is further made to honour God's continuing creation and God's continuing presence in God's creation. In light of this, the PBC has adopted a nature-centred approach as exemplified in the selected sermon, prayers strategic plan and vision 2040 .

It can be clearly perceived from the prayer stated above that there is the desire for a greening of all the country. The prayer anticipates that all dry patches be greened and that rains come as God is the rain maker. This prayer demonstrates God's activity in the affairs of humans and God's continuous intervention in creation. The reference to God as a rain maker in the prayer opens up for more parallels with African traditional religions (Maseno 2017). The sermon recognises the need for the waters by farmers. These waters would allow for the crops to grow and provide food for many people in Kenya. The dependence of humans on the earth and the reverse is clear in all its parts. Further, a metaphoric use of the word rain is made when rain is used as a reference for God's favour. One consequence of highlighting rain as a metaphor is that this may displace attention from actual ecological concerns.

\section{Youths, faith and the environment at Parklands Baptist Church}

The PBC has choirs and musical groups that provide the youths with space and forum for socialisation and even opportunities for forging new relationships and networks. As a place of worship, youths can associate with other worshippers before and after the services. The PBC creates space for voluntary associations of believers where they learn to forge new identities and make personal decisions.

The sermons that the youths hear allude to ecological concerns, which shows that to some extent PBC pays

4.The context of this excerpt is a prayer made on the listed date by another pastor of the Church. Being fully aware of the drought situation and dry spell in Kenya in January, the pastor prayed for the greening of the land and the rains to come. attention to the environment and this is important in shaping the youths to be environmentally conscious. Largely, the volunteers who are steering the vision 2040 projects and are lending a hand in the greening of $\mathrm{PBC}$ and its surrounding are the youths whose manpower is of great benefit to the congregation. It has been suggested that the younger generation are growing into ecological consciousness and reject the scepticism of their parents and grandparents. People roughly aged between 22 and 37 years - are far less likely than older generations to support the use of coal, oil and other fossil fuel sources (Neuhauser 2018:1). This correlates with a survey study carried out in 2018 and 2019 in USA that showed young people are more engaged in environmental issues such as global warming (Ballew et al. 2019).

The youths are deeply involved and plugged into the strategy 2040 which involves infrastructure development, grounds landscaping and the recreational facility enhancement. These projects as described are state of the art with the intention of having open space and green environment conducive for children and youths to enjoy. It is clear in this case that the environmental consciousness made explicit is the anthropocentric type whose pragmatic priority of human interests is in its interaction with the natural world.

Eco-theology is a particular expression of contextual theology that emerges in the distinct context of environmental awareness (Deane-Drummond 2008). Eco-theology considers ecological practices which have been suggested to include stewarding the land, decrying species loss, recycling and learning how to love God's creation. On the African continent, a lack of a single eco-theology opens room for several creative possibilities (Maseno 2020:338).

For analysis, this article considers the emerging eco-theology at $\mathrm{PBC}$ and its applicability appraised from tenets of a credible eco-theology (Davies \& Edward 2020). Youths at PBC glean from the sermons made at the church on environmental consciousness. They have also time and time again been involved in clean up campaigns, tree planting, beautification of the church premises, beautification of the main sanctuary and retreats in quiet and serene environments (PBC Website). Some of the aforementioned could instil pro environmental behaviour, awareness and attitudes among the youths through their lively participation.

The PBC regards the youths as any person who is not married and below the age of 40 years. The church has a youth ministry that primarily focuses on youths affairs, within the youth's sections, the youths having their own special sessions and programmes. Young people take the lead in organising events in church, leading programmes during Sunday service. The church having youth pastors is a way of nurturing the next generation of church leadership. It also inculcates responsibilities among the youths. The PBC considers the youths as important actors in mitigating the environmental crisis and being agents of environmental 
awareness in the society. As such, the church has used the youths to sensitise and conscientise the general public on the need to be concerned about the environment during the public cleaning exercises and community outreach sessions when they have in the Church precincts and when PBC youths go out in teams for bonding sessions and outreaches. Trained in caring for the immediate environment within the Church precincts, it is instructive that some youths would be able to carry this on into other spaces.

The large number of youths who attend services on a regular basis both physically and virtually in Pentecostal churches provide the church with an opportunity for ecological transformation of the youths through environmental awareness and sensitisation. The vision 2040 strategy framework encases green as central in the conducive and desired environment. Davies and Edward (2020:125) propose that a credible Christian eco-theology is a theology that stands the test of time on a number of fronts. Such an ecotheology ought to be gauged in the following ways. First, it ought to be culturally relevant. The youths who have plugged into the strategy framework, would find the green and conducive environment relevant to the congregation at large and also to themselves. The commitment of the youths to the Church and its vision focus is an aspiration for every PBC leader and mentor. Youths would be able to see the serenity that arises after their engagement with greening the church spaces and premises. This greening aspect would address the PBC context as applicable and appropriates the cultural artefacts and content in order to be robust and valid.

Second, such an eco-theology would be sensitive to the context of the PBC Christian community. The clarity in the strategic framework would take into consideration the Christian community in question in order to be credible. The related Christian tradition ought to inform the understanding of God's work on the planet.

Third, although this is but in the preliminary reflection stage, PBC youths developing such a grounded theology would promote a sustainable ecological engagement and praxis, finding expression in public worship, sermons, prayers and pilgrimages. This should make it possible to hear more songs and sermons around greening of the environment at PBC.

Even though the PBC church involves young people into environmental programmes and some of their sermons deals with environmental issues, it remains unclear the extent to which the teachings have an impact on their individual environment behaviours outside $\mathrm{PBC}$ precincts and without the community of other Church members.

\section{Conclusion}

The PBC vision 2040 and sermons demonstrate that there is a potential to making the spaces at the Church eco-friendly and green. The church is cognisant of the need to develop sustainably for future generations. They have also included a recreational facility where members and the youths can take time off. These spaces largely would connect individuals to creation and intended for use by all membership. Youths who have plugged into the strategy have taken steps to contextualise the greening and also promote ecological engagement thrugh sermons, prayers and songs. In all, the youths are in a space where they to some degree are exposed to a sensitivity to humanity embedded in nature and in some way equal with other part of creation as discerned from PBC. The effectiveness of their concerns besides prayer will need to be demonstrated rather much more clearly in the context of a public theology discourse, which engages Pentecostal sensibilities to provide a Pentecostal eco-theology, hence countering the critique of having seeming delinquent environmental attitudes (Swoboda 2013).

\section{Acknowledgements Competing interests}

The authors declare that they have no financial or personal relationships that may have inappropriately influenced them in writing this article.

\section{Authors' contributions}

L.M. contributed in conceptualisation, data collection and initial drafting of the manuscript. Both L.M. and K.M. contributed in analysis and interpretation of the data, critical revision of the manuscript, proofreading and the approval of the manuscript.

\section{Ethical considerations}

This article followed all ethical standards for research without direct contact with human or animal subjects.

\section{Funding information}

This research received no specific grant from any funding agency in the public, commercial or not-for-profit sectors.

\section{Data availability}

Data sharing is not applicable to this article as no new data were created or analysed in this study.

\section{Disclaimer}

The views and opinions expressed in this article are those of the authors and do not necessarily reflect the official policy or position of any affiliated agency of the authors.

\section{References}

Aasmundsen, H.G., 2016, Pentecostals, politics, and religious equality in Argentina, Brill, Boston, MA.

Anderson, A., 2002, 'The newer Pentecostal and Charismatic churches: The shape of future Christianity in Africa?', Pneuma 24(2), 167-184. https://doi. org/10.1163/15700740260388027

Ballew, M., Marlon, J., Rosenthal, S., Gustafson, A., Kotcher, J. \& Maibach, E. et al., 2019 Do younger generations care more about global warming?, Yale, Yale University and George Mason University, New Haven, CT, viewed 18 April 2021, from https:// climatecommunication.yale.edu/publications/do-younger-generations-care-moreabout-global-warming/. 
Bedford-Strohm, H., 2007, 'Tilling and caring for the Earth: Public theology and ecology', International Journal of Public Theology 1(2), 230-248. https://doi. org/10.1163/156973207X207353

Conradie, E.M., 2012, 'The church and the environment: Seven stations towards the sanctification of the whole Earth', Scriptura: Journal for Biblical, Theological and Contextual Hermeneutics 107(0), 156. https://doi.org/10.7833/107-0-133

Davies, K. \& Edward, N., 2020, 'A Southern African response to Todd LeVasseur and Bernard Zaleha', in E.M. Conradie and H.P. Koster (eds.), T \& T Clark handbook of Christian theology and climate change, pp. 21-39, Bloomsbury T \& T Clark, London.

Deane-Drummond, C., 2008, Eco-theology, 1st edn., Darton, Longman + Todd, London.

Goins, J.P., 1997, Expendable creation: Classical Pentecostalism and environmental disregard, University of North Texas, Denton, TX.

Golo, B.-W.K., 2014, 'The groaning Earth and the greening of neo-Pentecostalism in the 21st century Ghana', PentecoStudies: An Interdisciplinary Journal for Research on the Pentecostal and Charismatic Movements 13(2), 197-216. https://doi. org/10.1558/ptcs.v13i2.197

Howell, B., 2008, Christianity in the local context: Southern Baptists in the Philippines, Palgrave Macmillan, London.

Kaunda, C., 2015, 'Towards Pentecopolitanism: New African Pentecostalism and social cohesion in South Africa', African Journal on Conflict Resolution 15(3), viewed n.d. from https://www.ajol.info/index.php/ajcr/article/view/128536.

Kinyua, D., 2000, The impact of discipleship on Church growth: A case study of Parklands Baptist Church, Daystar University, Nairobi.

Liu, J., 2010, Historical overview of Pentecostalism in Kenya, Pew Research Center's Religion \& Public Life Project, 05 August, viewed 20 April 2021, from https://www. pewforum.org/2010/08/05/historical-overview-of-pentecostalism-in-kenya/.

Maseno, L., 2017, 'Prayer for rain: A Pentecostal perspective from Kenya', The Ecumenical Review 69(3), 336-347. https://doi.org/10.1111/erev.12297

Maseno, L., 2020, 'An African response to Christopher Vena', in E.M. Conradie and H.P. Koster (eds.), T \& T Clark handbook of Christian theology and climate change, pp. 336-339, Bloomsbury T \& T Clark, London.

McClendon, G.H. \& Riedl, R.B., 2015, 'Individualism and empowerment in Pentecostal sermons: New evidence from Nairobi, Kenya', African Affairs 115(458), 119-144. https://doi.org/10.1093/afraf/adv056

Neuhauser, A., 2018. 'On climate, sharp generational divide within GOP', US News, 14 May, 2018, viewed 20 July 2021, from https://www. usnews.com/news/nationalnews/articles/2018-05-14/on-climate-sharp-generational-divide-within-gop
Panov, V.I., 2013, 'Ecological thinking, consciousness, responsibility', Procedia-Socia and Behavioral Sciences 86, 379-383. https://doi.org/10.1016/j.sbspro. 2013.08.583

Parklands Baptist Church, 2019, Vision 2040 booklet, Parklands Baptist Church, viewed 19 April 2021, from https://parklandsbaptist.org/vision-2040/.

Parklands Baptist Church Website, n.d., Home, viewed 19 April 2021, from https:// parklandsbaptist.org.

Parsitau, D.S., 2014, 'The civic and public roles of neo-pentecostal churches in Kenya (1970-2010)', Doctoral thesis, Kenyatta University.

Parsitau, D.S. \& Mwaura, P.N., 2014, God in the city: Pentecostalism as an urban phenomenon in Ken' 2014, viewed 20 April 2021, from http://uir.unisa.ac.za/ bitstream/handle/10500/4631/Parsitau-Mwaura-SHEXXXVI_2_-October2010. pdf?sequence $=1$.

Sarrica, M., Brondi, S., Piccolo, C. \& Mazzara, B., 2016, 'Environmental consciousness and sustainable energy policies: Italian Parliamentary debates in the years 2009-2012', Society \& Natural Resources 29(8), 932-947. https://doi.org/10.108 0/08941920.2015.1095379

Shimron, R., Horton, G. \& Yonat, 2015, Southern Baptists change policy on speaking in tongues, viewed 19 April 2021, from https://www.charismanews.com/us/49661southern-baptists-change-policy-on-speaking-in-tongues.

Swoboda, A.J., 2013, 'Tongues and trees: Towards a Pentecostal ecological theology', in A.J. Swoboda \& A. Yong (eds.), Tongues and trees: Towards a Pentecostal ecological theology, Deo Publishing, Dorset.

Thunberg, G., 2019, Speaking at the UN's Climate Action Summit, viewed 20 April 2021 https://www.un.org/development/desa/youth/news/2019/09/greta-thunberg/.

UNFCCC, 2020, Climate change is an increasing threat to Africa, UNFCCC, United Nation Climate Change, viewed 19 April 2021, from https://unfccc.int/news/ climate-change-is-an-increasing-threat-to-africa.

White, L., 1967, 'The historical roots of our ecologic crisis', Science 155(3767), 1203-1207. https://doi.org/10.1126/science.155.3767.1203

World Council of Churches, 2016, Wcc statement on climate justice, viewed 16 July 2021 from https://www.oikoumene.org/resources/documents/wcc-statement-on-climatejustice.

World Council of Churches, 2021, Care for creation and climate justice, World Council of Churches, viewed 19 April 2021, from https://www.oikoumene.org/what-wedo/care-for-creation-and-climate-justice. 